\title{
SPECIFICS OF CRIMINAL LIABILITY FOR A BRUTAL AND PREMEDITATED MURDER UNDER THE CRIMINAL LEGISLATION OF SOME FOREIGN COUNTRIES
}

\author{
S.S. KOVALOVA, PhD (Law), \\ Senior Professor at the Administrative and Financial Law Department, \\ National University of Life and Environmental Sciences of Ukraine \\ E-mail: kovalyeva@gmail.com
}

\begin{abstract}
Summary. The article is dedicated to research on criminal liability for a brutal and premeditated murder under the criminal legislation of some foreign countries. It determines the principal trends in inflicting punishment for this type of an aggravated premeditated murder. It explains that the states of continental Europe and the countries of the Anglo-Saxon legal system have no common approach to incorporating a characteristic of a premeditated murder such as "extreme brutality» in their criminal legislations. It shows that the relevant characteristic is represented by a full scope of extreme brutality in the criminal laws of some states; other countries define just some aspects of extreme brutality; yet in a number of countries, extreme brutality is not defined as an aggravating circumstance of a murder at all. In other countries, although extreme brutality is not defined as a qualification, the elements of a crime are defined as a premeditated murder committed in a brutal way.
\end{abstract}

Keywords: a premeditated murder, an aggravating circumstance, extreme brutality, criminal liability, foreign legislation, legal systems, punishment

\section{Introduction.}

The world's contemporary practices point out that brutality in case of premeditated murders is on the rise, particularly when it comes to conflicts caused by various political, religious, military, and other confrontations. It is what makes us research the issue of criminal liability for a brutal premeditated murder under the criminal legislation of some foreign countries.

The article establishes that liability for crimes against life and health is provided in the criminal laws of all the foreign countries. However, the system of such criminal offenses, the methods of criminal liability regulation, and the frameworks of penalties sometimes differ significantly.

The results of research permitted to establish that the states of continental Europe and the countries of the Anglo-Saxon system of law have no common approach to incorporating a characteristic of a premeditated murder such as «extreme brutality» in their criminal legislations (Cherepii, 2013: 168-172). 
Life is a human being's most important, integral, and indefeasible right and good. Criminal law protection covers the life of any human whatever their social, demographic, and medical parameters.

These provisions are recorded in the most important international acts and fundamental sources: the Universal Declaration of Human Rights adopted and declared by the Resolution of the UN General Assembly dated December 10, 1948, the International Covenant on Civil and Political Rights adopted on December 16, 1966 by the UN General Assembly and ratified by the Order $« \mathrm{On}$ the Ratification of the International Covenant on Economic, Social, and Cultural Rights and the International Covenant on Civil and Political Rights» of the Presidium of the Verkhovna Rada (Supreme Council) of the Ukrainian Soviet Socialist Republic dated October 19, 1973.

Again, Article 3 of the Constitution of Ukraine declares that a human being, their life and health, honor and dignity, privacy and safety are defined as the highest social value in Ukraine. Consistent with Article 27 of the Constitution of Ukraine, every human has an integral right to life. No one may be arbitrarily killed. The state has an obligation to protect a human life. Building a state governed by the rule of law and making the Ukrainian society democratic imply recognizing that the universal human values, primarily a human life, are top priority.

As life is the main value protected by the state, crimes making an attempt on a human life are considered the most dangerous ones.

In the current situation, it is particularly important to rationally use the criminal law possibilities to identify and punish criminals and eliminate the growing threats to the security of an individual and the state. For this reason, the key purpose of legislation improvement is to bring the criminal law provisions in line with the real demands of the contemporary Ukrainian society and to use international experience

The purpose of the article is to study the specifics of criminal liability for a brutal and premeditated murder in various countries of the world.

\section{Analysis of recent studies and publications.}

The theoretical issues bearing on criminal liability for homicide both under the national laws and the legislation of foreign countries were studied by a large number of researchers in the late $19^{\text {th }}$ century and the early $20^{\text {th }}$ century: A.A. Piontkovsky, Sh.S. Rashkovska, M.D. Sharhorodsky, M.S. Tahantsev, A.N. Trainin, A.A. Zhyzhylenko and others. Nowadays, the following national researchers have contributed significantly to the resolution of the issues of the criminal law qualification of premeditated murders, including brutal ones: Yu.V. Aleksandrov, M.I. Bazhanov, Yu.V. Baulin, V.I. Borysov, V.K. Hryshchuk, O.V. Horokhovska, M.Y. Korzhansky, V.O. Navrotsky, A.V. Savchenko, Ya.H. Smiliansky, V.V. Stashys, V.Ya. Tatsiy, M.I. Khavroniuk, S.D. Shapchenko, S.S. Yatsenko and others.

However, the issue of criminal liability for a brutal and premeditated murder still needs to be better studied, specified, and detailed, which is caused by the specifics of this type of premeditated murders, certain imperfection of the criminal law provisions, insufficient development of some theoretical and applied aspects of the issue being analyzed, and also existence of errors in investigative and judicial practices when it comes to qualification of such premeditated murders and the need to eliminate the same. 


\section{Results.}

The criminal law system of each state is individual although some characteristics typical of any specific systems (families) of law are common. Implementation of international legal provisions in the national legislation system is a characteristic feature of the legal systems of many states. It should be emphasized that in most states, including in the post-Soviet ones, the first sections (chapters) of the special parts of the criminal code define the criminal law protection of the human life and health as the highest social value.

The contemporary world includes more than two hundred states, the criminal legislation of which has its own historical and legal specifics. Some provisions of foreign laws were taken into account by the Ukrainian lawmaker in the process of adopting the Criminal Law in 2001. At the same time, we believe that the principle of the supremacy of law failed to be implemented in full scope. This necessitated further studies of foreign experience. A study of the legislative source base of the European states showed that they are witnessing a creative process aimed at developing new criminal legislation based on democratic principles. Lawmakers focus on the studies and implementation of the criminal law provisions of the states with the oldest democratic traditions: Austria, France, Great Britain, Germany, the USA, etc.

Given the current phase of development of our state and its legal system, aggravated murders (Article 115 Section 2 of the Criminal Code) are studied and analyzed with reference to the relevant provisions of the criminal legislation of some foreign states (post-Soviet ones, states of the Romano-Germanic, Anglo-Saxon legal families, and some other states).
Just like the Ukrainian legislation, criminal liability for an aggravated murder is stipulated by the 1996 Criminal Code of the Russian Federation (Kommentaryi k Uholovnomu kodeksu Rossyiskoi Federatsyy, 2003), (Article 105) - 13 aggravating circumstances, the 1997 Criminal Code of the Republic of Kazakhstan (Uholovnyi kodeks Respublyky Kazakhstan, 2001) (Article 96) - 13 aggravating circumstances, the 1999 Criminal Code of the Republic of Belarus (Uholovnyi kodeks Respublyky Belarus, 2001) (Article 139) - 16 aggravating circumstances. This means that the lawmakers of the post-Soviet states chose to expand the list of aggravating circumstances to encompass circumstances formed by the theory and practice, changes in the life of society.

At the same time, the lawmaker of the Romano-Germanic and Anglo-Saxon legal families chose a different approach to the circumstances aggravating a murder by reducing their number.

In the Criminal Code of the Republic of Poland (Uholovnyi kodeks Respublyky Polsha, 2001), 234. Article 148 of Chapter 19 «Crimes against Life and Health» stipulates Clause 1 - liability for a second-degree murder such as imprisonment for at least 8 years, imprisonment for 25 years, or life imprisonment. Clause 2 provides for liability for a qualified murder. Circumstances aggravating liability include a brutal murder, a murder involving taking hostage, a rape or an assault; a murder involving the use of firearms or explosives; in addition, under Clause 3, individuals murdering two and more persons in one action or lawfully convicted for a murder earlier. These types of murders are liable for imprisonment for at least 12 years or imprisonment for 25 years or life imprisonment. 
Under Germany's Criminal Code (Uholovnyi kodeks FRG, 2001), Clause 211 of Chapter 16 «Criminal Offences against Life» stipulates criminal liability for «an aggravated murder"» under aggravating circumstances such as a murder for sadistic motives, for satisfying sexual desires, for selfish and other dishonest motives, a murder committed in a cruel or generally dangerous way, aimed at hiding any other criminal acts or facilitating the same. Such crimes are punished solely with life imprisonment.

Under Austria's Criminal Code (Uholovnyi kodeks Austria's, 2011), Clause 75 of Chapter 1 of the Special Section «Criminal Offences against Life and Health" provides for liability for "an aggravated murder», which is punished by imprisonment for a period from ten to twenty years or life imprisonment.

Under Spain's Criminal Code (Uholovnyi kodeks Yspanyy, 2008), in Book 2 «Crimes and Punishment» Article 138 of Chapter 1 «Murders and its Types» provides for criminal liability for a second-degree murder punishable by imprisonment for a period from 10 to 15 years, whereas Articles 139 and 140 set liability for a murder under aggravating circumstances such as breach of faith, for consideration or a promise, with brutality. Such murders result in punishment such as imprisonment for a period from 15 to 20 years, and, under Article 140, murders under two or more aggravating circumstances are punishable with imprisonment for a period from 20 to 25 years.

Under the criminal legislation of Great Britain, Article 1 of the Homicide Act 1957, the qualification of a premeditated murder as an aggravated (qualified) one is defined by only one circumstance: deliberate malice. It is fixed in cases where the convict's actions are premeditated; they intend to unlawfully kill another individual, unlawfully cause grave bodily injuries to another individual. The other circumstance is the one that caused death. The UK's criminal laws define a brutal murder as the most serious type of homicide (Uholovnoe pravo zarubezhnыykh hosudarstv, 2012).

The specifics of criminal liability for homicide under English legislation consist in the following: apart from homicide, i.e. causing the victim's death as a result of shooting, stabbing, or using other dangerous objects, poisoning, etc., «an aggravated murder was mentioned even in connection with deliberately endangering an individual in an unacceptable and obvious manner, for instance, placing a prisoner in a cell with another prisoner suffering from the smallpox». This approach is caused by the definition of an aggravated murder construed «not just as death caused to another individual, but a deliberate action preceded by willful malice» (Uholovnoe pravo zarubezhnykh hosudarstv, 2012).

Similar murders are defined and qualified in the same way under France's laws as well (Articles 221-3 of the Criminal Code) (Uholovnyi kodeks Frantsyy, 2014).

Under the criminal laws of some states of the United States of America, in particular the Criminal Code of the State of New York (Uholovnoe pravo SShA, 2015), Chapter H «An Attempt on an Individual's Life ...», Clause 125.00 of Article 125 «Homicide ...» provides a definition of homicide: «homicide means an act causing death to a person or an unborn child a woman was pregnant with for over 24 weeks, under circumstances due to which an attempt is qualified as an aggravated murder, a first- and second-degree murder, a mur- 
der caused by criminal negligence ...». Consistent with Clause 125.27, an aggravated first-degree murder will take place under the following aggravating circumstances:

- the victim was a police officer killed while performing their official duties and the convict was aware that the victim was a police officer;

- the victim was an officer of a penitentiary facility of the state or a local body killed under the same circumstances as the police officer;

- during the murder, the convict was forcefully held in a penitentiary, detained following a sentence (under some circumstances), or was escaping from this penitentiary or a detention center.

Such crimes are subject to capital punishment, unless the jurors issue a verdict with an instruction not to apply capital punishment. In this case, life imprisonment is imposed. Generally, under the laws of the United States of America, apart from the aforementioned aggravating circumstances, there are other circumstances such as selfish motives, contract killing, homicide committed along with other violent selfish crimes, etc. (Uholovnoe pravo SShA, 2015).

\section{Conclusions and prospects.}

This study demonstrates that the states of continental Europe and the countries of the Anglo-Saxon legal system have no common approach to incorporating a qualifying characteristic of a premeditated murder such as «extreme brutality» in their criminal legislations. This qualification is not defined as an aggravating circumstance of a murder or exists only in some of its aspects and is not represented in full scope in certain cases. In the legislation of most post-So- viet states, extreme brutality is defined as a qualifying characteristic of a murder. In addition, the criminal legislation of western countries (the USA, England, France, Germany, Austria) imposes liability only for two types of premeditated murders: the so called "second-degree» and «aggravated» homicide, i.e. a murder under aggravating circumstances. Their list is defined at a legislative level; their number is small and tends to get reduced. What does not change is that in all the countries extreme brutality is defined as an aggravating circumstance of a premeditated murder.

\section{References}

1. Cherepii, P.P. (2013). Do pytannia vyznachennia osoblyvoi zhorstokosti za kryminalnym zakonodavstvom zarubizhnykh krain [On the issue of determining special cruelty under the criminal law of foreign countries]. Pravova systema Ukrainy: suchasnyi stan ta aktualni problemy: materialy druhoi vseukrainskoi naukovopraktychnoi konferentsii . Ivano-Frankivsk, 168-172 (in Urainian).

2. Kommentaryi $\mathrm{k}$ Uholovnomu kodeksu Rossyiskoi Federatsyy [Commentary on the Criminal Code of the Russian Federation]. Rasshyrennyi uholovno-pravovoi analyz s materyalamy sudebno-sledstvennoi praktyky (2003). Moskva: «Ekzamen», 880 (in Russian).

3. Uholovnyi kodeks Respublyky Kazakhstan [Criminal Code of the Republic of Kazakhstan] (2001). SPb.: «lurydycheskyi tsentr Press», 466 (in Russian).

4. Uholovnyi kodeks Respublyky Belarus [Criminal Code of the Republic of Belarus] (2001). SPb.: "lurydycheskyi tsentr Press», 474 (in Russian).

5. Uholovnyi kodeks Respublyky Polsha [Criminal Code of the Republic of Poland] (2001). SPb.: «lurydycheskyi tsentr Press», 234 (in Russian). 
6. Uholovnyi kodeks FRG [Criminal Code of the Federal Republic of Germany] (2001). Moskva: «Zertsalo», 208 (in Russian).

7. Uholovnyi kodeks Austria's [Criminal Code of Austria] (2011). Moskva: «Zertsalo», 108 (in Russian).

8. Uholovnyi kodeks Yspanyy [Criminal Code of Spain] (2008). Moskva, 218 (in Russian).
9. Uholovnoe pravo zarubezhnykh hosudarstv. Obshchaia chast [Criminal law of foreign states] (2012). Moskva, 576 (in Russian).

10. Uholovnyi kodeks Frantsyy [French Penal Code] (2014). Moskva, 650 (in Russian).

11. Uholovnoe pravo SShA: sbornyk normatyvnykh aktov [US Criminal Law Compilation of Regulations] (2015). Moskva, 260 (in Russian).

\section{С.С. КовальОва (2020). ОСОБЛИВОСТІ КРИМІНАЛЬНОї ВІДПОВІДАЛЬНОСТІ

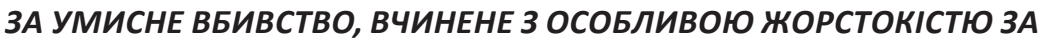 КРИМІНАЛЬНИМ ЗАКОНОДАВСТВОМ ОКРЕМИХ ЗАРУБІЖНИХ ДЕРЖАВ.}

Право. Людина. Довкілля, 11(3): 160-165. https://doi.org/10.31548/law2020.03.019.

Анотація. Стаття присвячена дослідженню кримінальної відповідальності за умисне вбивство з особливою жорстокістю за кримінальним правом окремих зарубіжних держав. Визначено основні тенденції призначення покарання за цей різновид умисного вбивства за обтяжуючих обстави.Обгрунтовано, що в державах континентальної Європи та в країнах англосаксонської системи права немає єдиного підходу щодо відображення в кримінальному законодавстві такої ознаки умисного вбивства, як "особлива жорстокість». Встановлено, що у кримінальних законах окремих держав відповідна ознака представлена повним проявом особливої жорстокості; в деяких країнах виділяються лише окремі прояви особливої жорстокості; в ряді країн особлива жорстокість взагалі не визначається як обтяжуюча обставина вбивства. В інших країнах, хоча прямо й не передбачено особливої жорстокості, як кваліфікуючої ознаки, склад злочину визначається як умисне вбивство, вчинене особливо жорстоким способом.

Ключові слова: умисне вбивство, обтяжуюча обставина, особлива жорстокість, кримінальна відповідальність, зарубіжне законодавство, правові систем, покарання 